\title{
Large Mammal Diversity in Nensebo Forest, Southern Ethiopia
}

\author{
Zerihun Girma $\mathbb{D}^{1}$ and Zerubabel Worku ${ }^{2}$ \\ ${ }^{1}$ Hawassa University, Wondo Genet College of Forestry and Natural Resources, \\ Department of Wildlife and Protected Area Management, Shashemene, Ethiopia \\ ${ }^{2}$ GIZ-Biodiversity and Forestry Program (BFP), Addis Ababa, Ethiopia \\ Correspondence should be addressed to Zerihun Girma; zeru75@yahoo.com
}

Received 27 September 2020; Revised 29 November 2020; Accepted 4 December 2020; Published 19 December 2020

Academic Editor: Joao Pedro Barreiros

Copyright (c) 2020 Zerihun Girma and Zerubabel Worku. This is an open access article distributed under the Creative Commons Attribution License, which permits unrestricted use, distribution, and reproduction in any medium, provided the original work is properly cited.

\begin{abstract}
There is a lack of information on mammalian faunal resources of remote forests in Ethiopia; as a result, the findings of the research on large wild mammals at Nensebo forest is one of the steps in a continuing effort to document and describe the diversity and distribution of Ethiopian mammals in remote and less accessible forests. The survey was conducted to assess the species composition and relative abundance of large mammals. Two standardized survey techniques, direct (sighting/hearing) and indirect (scat/footprint), were employed using systematically established transect lines and field plots in two dominant habitat types (modified moist Afromontane forest and intact moist Afromontane natural forest) of the study area. A total of 16 species were recorded including two endemic mammals, namely, Tragelaphus buxtoni and Tragelaphus scriptus meneliki. Abundance of species among different habitat types was not significantly different $\left(\chi^{2}=0.125, \mathrm{df}=1, p>0.05\right)$, and Colobus guereza was the most abundant species. In contrast, Felis serval, Panthera leo, and Tragelaphus buxtoni were the least abundant species. The highest diversity index was recorded in the natural forest habitat $\left(H^{\prime}=2.188\right)$, and the modified forest had the lowest diversity index $\left(H^{\prime}=1.373\right)$. There is an urgent need to minimize threats and mitigate impacts.
\end{abstract}

\section{Introduction}

Mammals provide ecological, economic, sociocultural, and educational and scientific services in a particular ecosystem [1-6]. They are one of the most widely distributed organisms in the world. Mammals are successful in colonizing diverse habitat types due to diversity in morphological, physiological, and behavioral adaptations and hence exist from the Antarctic to desert regions [6, 7]. They exhibit great diversity in size and forms. Particularly, range from the smallest Kitti's Hog-Nosed Bat (Craseonycteris thonglongyai) (2 $\mathrm{g})$ to the giant blue whale (Balaenoptera musculus) $(140,000 \mathrm{~kg})$ [1]. Those that weigh above $7 \mathrm{~kg}$ are called large mammals $[1,8]$. There have been discoveries of new taxa over the past decades; as a result, the number of mammalian species has been continuously updated. According to the most recent (3rd) edition of the standard taxonomic reference work, Mammal Species of the World [1], the class Mammalia comprises 5416 species. The largest groups are rodents (Rodentia, 42\%), bats (Chiroptera, 20.6\%), and their Allies (Soricomorpha, 7.9\%).

Ethiopia is one of the top 25 biodiversity-rich countries in the world, and hosts two of the world's 34 biodiverse hotspots, namely, the Eastern Afromontane and the Horn of Africa hotspots $[9,10]$. It is one of the countries with the most diverse mammalian faunas in Africa [6, 7]. It is estimated that there are about 320 species, including 39 endemics (both small and large mammals), distributed in 14 orders and 39 families [11-13]. Furthermore, the country is known as "Home of the Unique Seven" which refers to seven distinctive and large endemic mammals found only in Ethiopia [14], namely, the Ethiopian wolf (Canis simensis), mountain nyala (Tragelaphus buxtoni), walia ibex (Capra walle), Menelik's bushbuck (Tragelaphus scriptus meneliki), Swayne's hartebeest (Alcelaphus buselaphus swaynei), gelada baboon (Theropithecus gelada), and bale monkey (Chlorocebus djamdjamensis) $[13,14]$. 
A number of large mammal diversity studies have been carried out in various protected areas of Ethiopia [15-18]. However, the faunal records of the country are underestimated since most studies have focused on protected areas [15], where large mammals are mainly concentrated in the south and southwest border and adjacent area. Several reports have also emphasized the importance of habitats outside protected areas in supporting large mammal diversity, but there have been few surveys of these sites and comprehensive baseline information is lacking [13]. However, protected areas alone cannot sustain large mammals. First, only a small proportion $\left(186,000 \mathrm{~km}^{2}\right.$, equivalent to $16.4 \%$ of Ethiopia's surface area) of Ethiopia's landmass is legally protected [13]. Second, large mammals often travel long distances outside of protected areas to fragmented forest patches due to seasonal variations of resources. As a result, wildlife depends on land adjacent to these protected areas for continued viability. They may use these adjacent lands as critical dispersal areas, calving grounds and/or for other seasonal movement between protected areas. However, there has been little understanding of how the ecosystems function and large mammals survive especially in human dominated landscapes.

Nensebo forest, a patch of moist Afromontane forest (MAF), is partly connected to the Bale Mountains National Park (BMNP). However, this corridor has continued human encroachment that often challenges wildlife movement between the two areas of habitat. Large mammals such as mountain nyala and lion (Panthera leo) may move seasonally between these two habitat areas. However, there is no scientifically documented information about which large mammal species are restricted to the forest area, which are the most abundant, or on population structure or habitat use of resident species. Likewise, there is a need of information on the species diversity for the large mammal population to underpin management actions and integrate sustainable conservation of the wildlife resource in BMNP and forest fragment.

The aim of the present study was therefore to describe the species composition, relative abundance, and population structure and habitat use of large mammals in Nensebo forest to underpin future management.

\section{Materials and Methods}

2.1. Study Area. Nensebo forest is found in Nensebo Woreda (district) in west Arsi Zone of Oromia Regional state of Ethiopia (Figure 1). The district is situated between $6^{\circ} 10^{\prime}$ and $6^{\circ} 40^{\prime} \mathrm{N}$ longitudes and $39^{\circ} 0^{\prime}$ and $39^{\circ} 40^{\prime} \mathrm{E}$ latitudes (Figure 1 ). It is located $407 \mathrm{~km}$ from Addis Ababa and $134.5 \mathrm{~km}$ from Shashemene, the capital city of West Arsi zone. Nensebo Woreda is bordered by eight districts (Kokosa, Dodola, Adaba, Bensa, Girja, Meda Welabu, Chire, and Harenna Buluk), administered under four administrative zones (West Arsi, Bale, Borena, and Sidama zones) and shared between two regional states (Oromia Regional State and South Nations and Nationalities People Regional State, SNNPRS) (Figure 1).
The district is characterized by mountainous landscape having an altitude range between $1500 \mathrm{~m}$ above sea level (a.s.l) and $3700 \mathrm{~m}$ a.s.l. The Woreda exhibits a bimodal rainfall pattern, with the annual rainfall range between 900 and $1100 \mathrm{~mm}$ and with a temperature that varies between a minimum of $15^{\circ} \mathrm{C}$ and a maximum of $22^{\circ} \mathrm{C}$ [19]. Nensebo forest is a moist Afromontane forest jointly managed by community and Oromia forest and Wildlife Enterprise. Nensebo forest is part of Bale Mountains Ecoregion known for its rich biodiversity and high level of endemism. The forest is one of remnant moist MAF in the southeastern part of Ethiopia that exists in a human dominated landscape [20]. The total area of Nensebo forest is 5199 ha, of which 3168 ha is relatively intact MAF and 2031 ha is modified MAF.

2.2. Reconnaissance Survey. A reconnaissance survey was carried out to obtain basic information on accessibility, topography, and dominant habitat types during the last week of April, 2017. Based on the land cover features, the study site was stratified in to two dominant habitat types, namely intact MAF (Figure 2) and modified MAF. MAF is characterized by dominant stands of the indigenous tree species such as Croton macrostachys, Strychnos spinosa, Clematis longicauda, Prunus africana, and Millettia ferruginea [20]. In the reconnaissance survey, sampling design, and data collection, we followed the method of [21]. The forest occurred over mountain slopes, valleys, and remote inaccessible areas. The level of disturbance was minimal, there were no settlements or cultivation, and hardly livestock grazed in the area (Figure 2). Modified moist MAF (habitat) occurred relatively at lower altitudes (1882-2153 m.a.s.l) in close proximity to human settlement and cultivation areas. Modified habitat is characterized by sparse stands of moist Afromontane characteristic tree species with low level crop cultivation (mainly "enset" and coffee), intense livestock grazing, and sparse human settlements (Figure 3) [22].

2.3. Sampling Design. To effectively survey the species diversity and abundance of large mammals, two standardized survey techniques, direct (line transect; sighting/hearing) and indirect (plots; scat) census were followed [8]. Both the transect lines and field plots were laid/set lengthwise, following the slope of the ground and oriented perpendicular to ecological or density gradients. Aspect, accessibility, terrain, long roads, streams, and contour of hills are also considered during the transect lines and plots setup. Both direct (transect lines) and indirect survey (plots) were systematically generated using geographic information system [23] with the help of QGIS V2.18 software.

2.3.1. Direct Survey. A total of 20 (T1-T20) fixed length and systematic parallel line transect lines were established (Figure 4(a)). Line transects were oriented in a parallel direction and pointed north to south direction against altitudinal gradient. The distance between two adjacent transects was $1000 \mathrm{~m}$ to avoid double-counting and edge effect; transects were spaced $500 \mathrm{~m}$ from the edge of the 


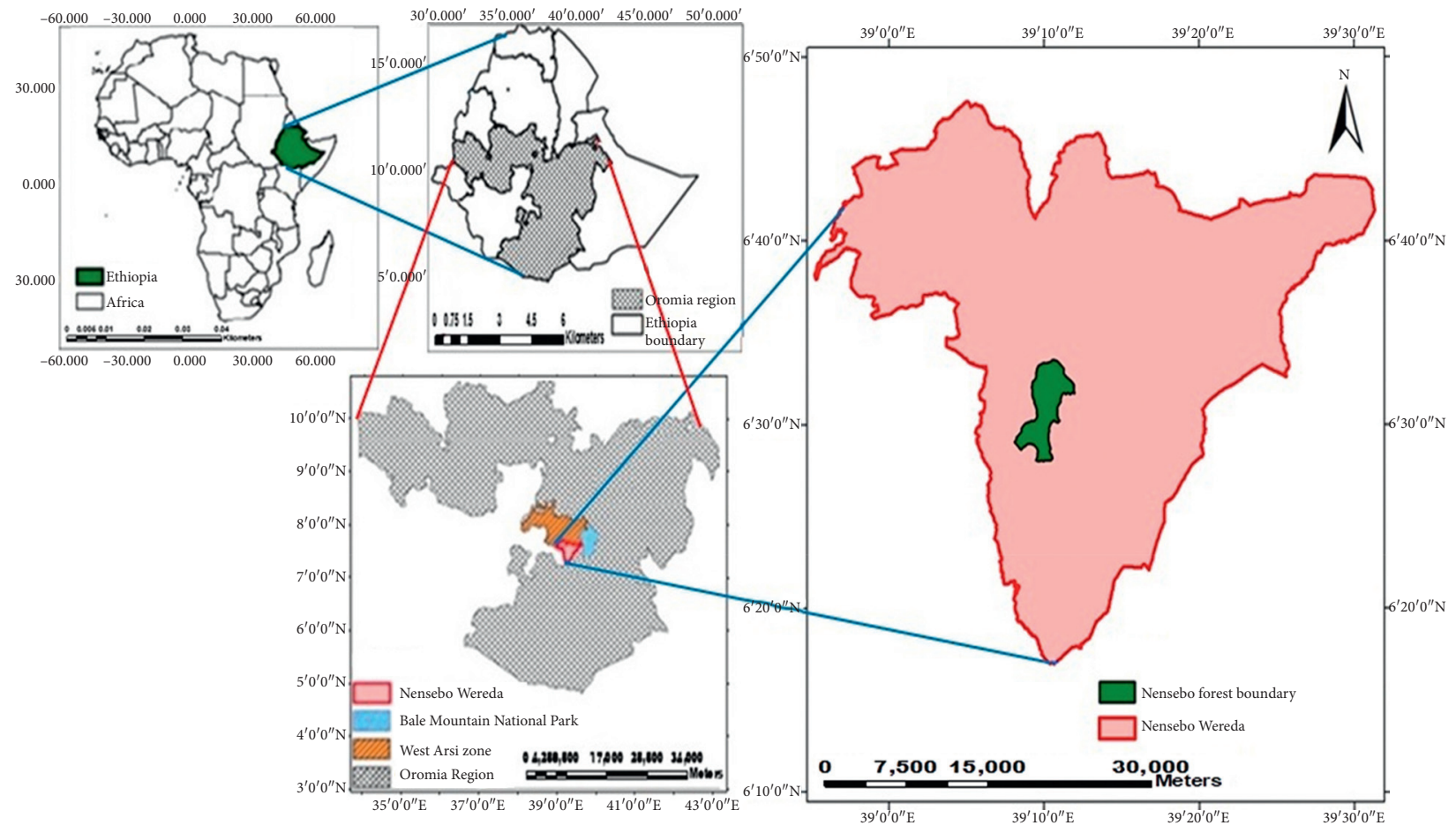

FIGURE 1: Location map of study area.
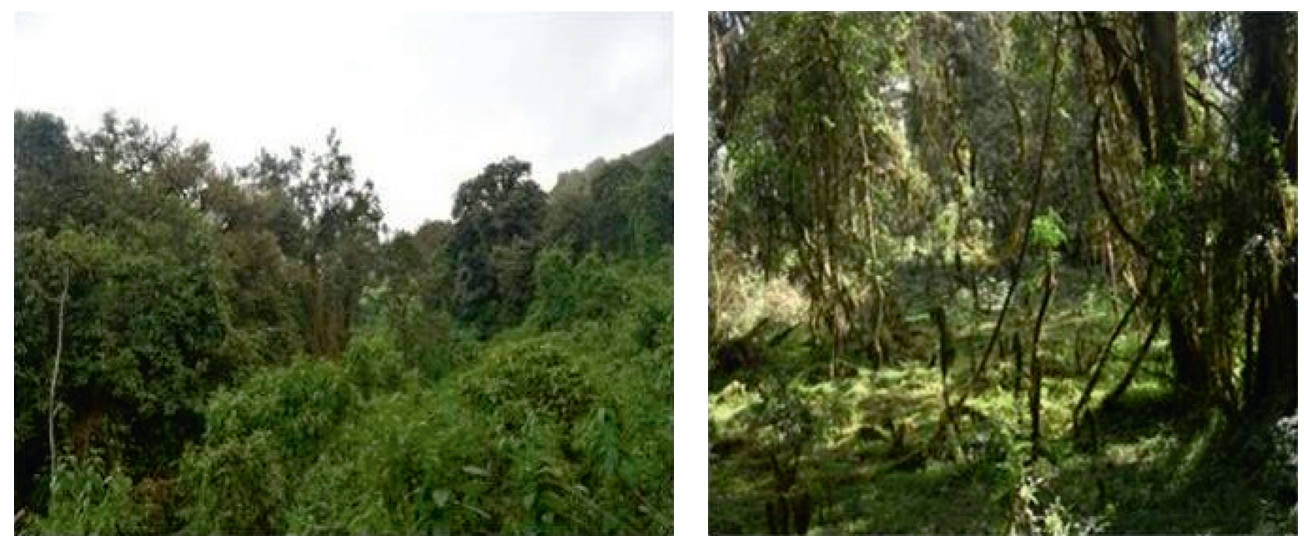

(a)

Figure 2: The intact moist Afromontane habitat at Nensebo forest, Southern Ethiopia (photo: Zerubabel Worku, 2018).
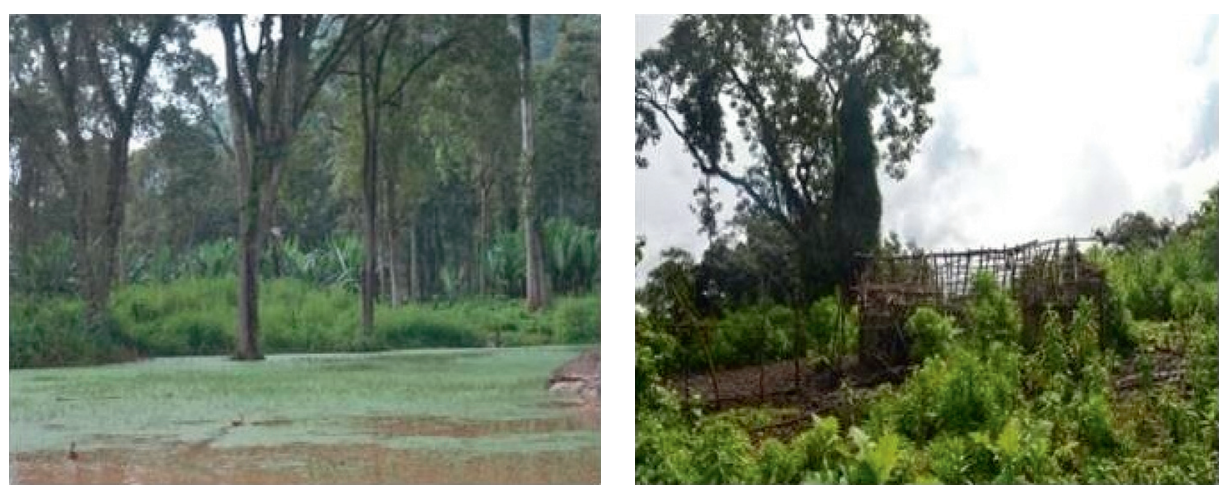

(a)

Figure 3: The modified MAF habitat at Nensebo forest, Southern Ethiopia (photo: Zerubabel Worku, 2018). 


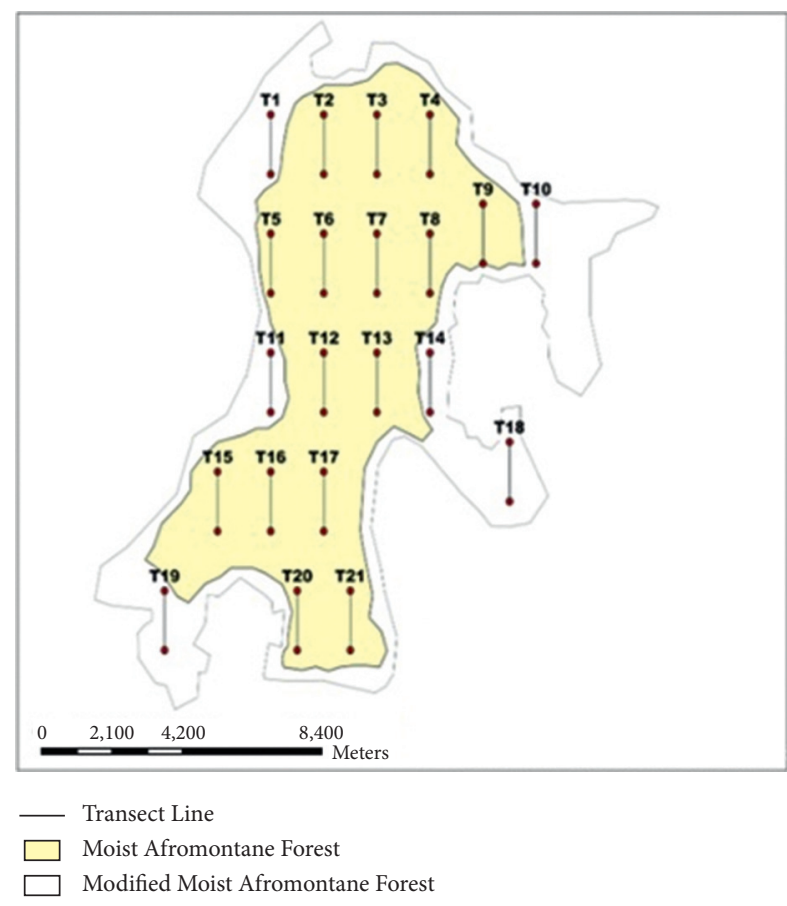

(a)

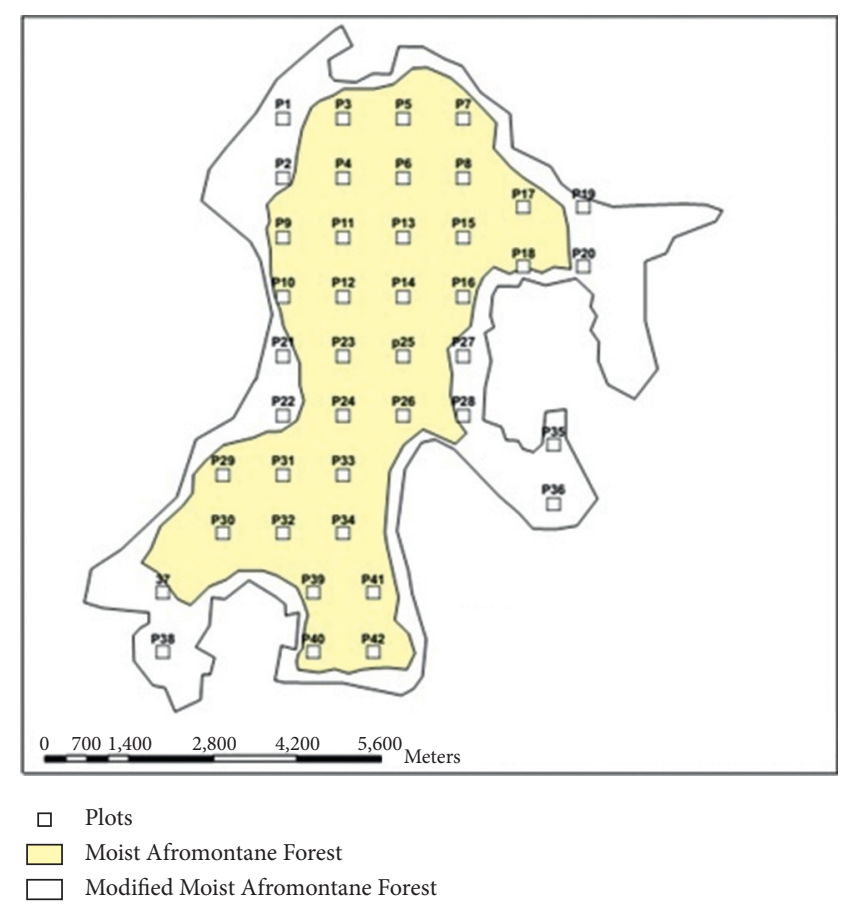

(b)

FIgURE 4: (a) Line transects layout and (b) plots layout at Nensebo forest, southern Ethiopia.

forests. Information from the pilot study, field observation, and land cover analysis and approximate area of each habitat type in the study areas were used to determine the proportion of sample transects needed to represent each habitat type. Accordingly, from the total of 21 transect lines, six transect lines were established in the modified MAF and 15 transect lines were established in the intact MAF (Figure 4(a)). The length of each transect was $1000 \mathrm{~m}$, and sighting distance varied between $10 \mathrm{~m}$ in dense MAF and $100 \mathrm{~m}$ in the open modified MAF. Furthermore, to avoid double-counting natural barriers such as mountains, valleys and streams and other biophysical features were considered in establishing transects.

2.3.2. Indirect Survey. Due to the elusive nature of the mammals, difficult topography and relatively dense vegetation cover indirect survey was also employed to assess the presence of rare and nocturnal mammals. From the pilot study, field observation, and land cover analysis, the approximate area of each habitat type in the study area was determined and was used to determine the proportion of sample plots needed to represent each habitat type. Accordingly, a total of 42 plots (P1-P42) spaced $1000 \mathrm{~m}$ apart were established (Figure 4(b)). A total of 12 plots were established in the modified MAF, and 28 plots were established in the intact MAF (Figure 4(b)). The size of each plot was $100 \mathrm{~m}^{2}(20 \times 5 \mathrm{~m})$. The plots were established following the transect lines established for the direct survey.

2.4. Data Collection. The study was conducted between the months of July 2017 to February 2018 covering both dry
(January to February 2018) and wet (July to August 2017) seasons. Each transect line/plot was visited six times per season.

2.4.1. Direct Survey. Mammalian populations were counted by direct observation along the established transect lines, during morning hours (6:00 to 10:00 am) and late afternoon $(3: 00$ to $5: 00 \mathrm{pm})$ according to $[24,25]$. Each line transect was navigated by using a Garmin 60/78 Global Positioning System (GPS) and Handheld Bearing Compass Suun to KB-14/360R G by gently walking at a constant speed of $\sim 1 \mathrm{~km} / \mathrm{h}$ [25-27]. During the study periods, the silent detection method (suitable clothing for camouflage, moving opposite wind direction (from south to north), and avoiding loud voices) was practiced minimizing disturbance. Observations were made with naked eyes and Nikon action $10 \times 50$ binocular.

Body weight was the parameters used to categorize mammals as large-sized. Data collected for all individuals observed were approximate perpendicular distance, sex, age, group size, and activity of the animals. Morphological development (horn ridges, horn size, and body size), growth and maturation, changes in pelage color or patterns, and sexual maturity (bacula, testes length, condition of mammary glands, and behavior during breeding) were used to determine the approximate age (adult, subadult, and young/ calf) [28].

Secondary sexual characteristics, external genitalia and behavior (urination posture, vocalizations, nipples, presence and absence of bacula, and descended testes), and sexually dimorphic characteristics (such as absence/presence of 
horn) were used to determine sex. Those individuals seen within a distance of $<50 \mathrm{~m}$ from the nearby group were recorded as members of the same group [27, 28]. Double counting of the same individual or herd was avoided using easily recognizable features of individuals, herd size, and composition [15, 27, 28]. Furthermore, trained field assistants were employed to survey transects located at similar topographic landscape at the same time to minimize movements of animals between transects, hence avoiding double-counting.

For a more complete species list, in addition to fixed line transects surveys, random searches were held to record the occurrence of mammalian species in the study areas during both day and night time (using hand torch) for five days and nights in each season searching them in potential habitats and areas inaccessible with transect lines and plot survey methods [26]. Species identification of mammals was based on The Kingdon Field Guide to African Mammals [29] and "Atibiwoch" [30]. For taxonomic treatment of the results, Mammal Species of the World $3^{\text {rd }}$ Edition [1] was adopted.

2.4.2. Indirect Survey. Each field plot was scanned carefully, and all fresh scats of wild animals were counted and recorded. Identification of scats obtained was attempted in the field by using specialized field guides for the identification of scats $[8,31-33]$. Scats were distinguished for each species using parameters' size (measurement of length and diameter), shape, odor, color, and signs associated with feces, such as scrapes, feeding signs, and footprint.

2.5. Data Analysis. The conservation status of each species was also identified based on the IUCN Red List [34] and the CITES Appendices. Following [35], the identified mammals were grouped as common (if there was $100 \%$ chance of recording the species in all field trips), uncommon (recorded $>50 \%$ of field trips), and rare (if probability of recording is less than 50\%) [35].

The number of individual mammals recorded from a specific habitat type on the same line transect was recorded as a sample from one habitat. Each individual of a species was grouped in different group size-class and age-sex categories and ratios, that is, percentages of adults and young ones, male per female, and young ones per female. The effect of the season on species abundance and distribution among dry and wet season was also analyzed and compared using Chi-square test, and the seasonal difference in sex ratio was evaluated by $t$-test.

Species diversity among the two dominant habit types in the forest was calculated using the Shannon-Weiner index $\left(H^{\prime}\right)$ of diversity [36]:

$$
\left(H^{\prime}\right)=\sum_{i=1}^{s} P_{i} \ln P_{i},
$$

where $P_{i}$ is the proportion of the $i^{\text {th }}$ species in the habitat.

In addition to the Shannon-Weiner index of diversity, Simpson's diversity index $(D)$ was used to calculate the species diversity among the two dominant habit types in the forest using [37]

$$
(D)=\frac{1}{\sum_{i=1}^{s} P_{i_{2}}},
$$

where $P_{i}$ is the proportion of the $i^{\text {th }}$ species, which will be used to analyze the data.

The similarity among and between the habitats with reference to the composition of species was computed using Sorenson's coefficient (CC) [38]:

$$
(\mathrm{CC})=\frac{2 \mathrm{C}}{S_{1}+S_{2}},
$$

where $C$ is the number of species the two habitats have in common, $S_{1}$ is the total number of species found in habitat 1 , and $S_{2}$ is the total number of species found in habitat 2.

The evenness of mammalian species was also calculated as [39]

$$
J=\frac{H^{\prime}}{H^{\prime} \max },
$$

where $H^{\prime} \max =\ln (s)$ and $s$ is the number of species. This measure varies between 1 (complete evenness) and 0 (complete unevenness).

The relative abundance of the large mammals was determined by using [40]

$$
\text { Relative abundance }(\%)=\frac{n}{N} \times 100 \text {, }
$$

where $n$ is the number of individuals of a recorded species and $N$ is the total number of individuals of recorded species. The results and findings of the research were presented by simple descriptive statistical tools.

\section{Results}

3.1. Species Composition. A total of 16 species of large mammals grouped into nine families and five orders were recorded after a total effort of $80 \mathrm{~km}$ walked. One endemic and endangered (mountain nyala) and another endemic subspecies Menelik's bushbuck were recorded from the fragmented forest (Table 1). The most abundant order was Artiodactyla (41\%, 6 species), while Rodentia and Tubulidentata were the rarest, represented by single species each. Out of the total 16 species of large mammals recorded, 10 were recorded using both direct evidences (direct sighting or hearing) and indirect evidences (scat or foot print), two species with direct evidence only, and the rest four were recorded only through indirect evidences (scat or foot print) (Table 2; Figure 5).

Seasonal variation in species composition for some large wild mammals was observed (Figure 6). For instance, serval cat, lion, and mountain nyala were not recorded during dry season. However, the seasonal variation in the number of species of large wild mammals was not significantly different $\left(\chi^{2}=0.125, \mathrm{df}=1, p>0.05\right)$. Conversely, the abundance of mammals varied seasonally. A total of $920 \pm 21$ individuals of large mammals were recorded, from which $544 \pm 16$ (59.1\%) 
TABLE 1: Large mammal species composition and their conservation status at Nensebo forest, Southern Ethiopia.

\begin{tabular}{|c|c|c|c|c|c|}
\hline Taxon (scientific name) & Common name & IUCN status & CITES status & Occurrence status & Local status \\
\hline \multicolumn{6}{|l|}{ Order Artiodactyla } \\
\hline \multicolumn{6}{|l|}{ Family Bovidae } \\
\hline Tragelaphus buxtoni Lydekker, 1910 & Mountain nyala & Endangered & - & Endemic & Rare \\
\hline Tragelaphus scriptus meneliki Neumann 1902 & Menelik's bushbuck & Least concern & & Endemic & Rare \\
\hline Sylvicapra grimmia Linnaeus, 1758 & Common duiker & Least concern & - & Native & Uncommon \\
\hline Family Suidae & & & - & & \\
\hline Phacochoerus africanus Gmelin, 1788 & Common warthog & Least concern & & Native & Common \\
\hline Hylochoerus meinertzhageni Thomas, 1904 & Giant forest hog & Least concern & - & Native & Uncommon \\
\hline Potamochoerus larvatus F. Cuvier, 1822 & bush pig & Least concern & - & Native & Uncommon \\
\hline Order Carnivora & & & - & & \\
\hline \multicolumn{6}{|l|}{ Family Canidae } \\
\hline Canis aureus Linnaeus, 1758 & Common jackal & Least concern & - & Native & Uncommon \\
\hline \multicolumn{6}{|l|}{ Family Haenidae } \\
\hline Crocuta crocuta Erxleben, 1777 & Spotted hyena & Least concern & - & Native & Common \\
\hline \multicolumn{6}{|l|}{ Family Felidae } \\
\hline Panthera pardus Linnaeus, 1758 & Leopard & Vulnerable & Appendix I & Native & Rare \\
\hline Panthera leo Linnaeus, 1758 & Lion & Vulnerable & Appendix II & Native & Rare \\
\hline Felis serval Schreber, 1776 & Serval cat & Least concern & Appendix II & Native & Rare \\
\hline \multicolumn{6}{|l|}{ Family Viverridae } \\
\hline Civettictis civetta Schreber, 1776 & African civet & Least concern & Appendix III & Native & Rare \\
\hline \multicolumn{6}{|l|}{ Order Primates } \\
\hline \multicolumn{6}{|l|}{ Family Cercopithecidae } \\
\hline Papio anubis Lesson, 1827 & Olive baboon & Least concern & Appendix. II & Native & Uncommon \\
\hline Colobus guereza Rüppell, 1835 & Colobus guereza & Least concern & Appendix II & Native & Common \\
\hline \multicolumn{6}{|l|}{ Order Rodentia } \\
\hline \multicolumn{6}{|l|}{ Family Hystricidae } \\
\hline Hystrix cristata Linnaeus, 1758 & Crested porcupine & Least concern & - & Native & Uncommon \\
\hline \multicolumn{6}{|l|}{ Order Tubulidentata } \\
\hline \multicolumn{6}{|l|}{ Family Orycteropodidae } \\
\hline Orycteropus afer Pallas, 1766 & Aardvark & Least concern & - & Native & Uncommon \\
\hline
\end{tabular}

TABLe 2: Large mammal species reordered with direct evidences and indirect evidences from Nensebo forest, Southern Ethiopia.

\begin{tabular}{lcc}
\hline Species name & Recorded with direct evidences (sighting or hearing) & Recorded with indirect evidences (scat or foot print) \\
\hline Canis aureus & Yes & Yes \\
Colobus guereza & Yes & Yes \\
Crocuta crocuta & Yes & Yes \\
Hylochoerus meinertzhageni & Yes & Yes \\
Felis serval & Yes & No \\
Panthera pardus & Yes & Yes \\
Papio anubis & Yes & Yes \\
Phacochoerus africanus & Yes & Yes \\
Potamochoerus larvatus & Yes & No \\
Sylvicapra grimmia & Yes & Yes \\
Tragelaphus scriptus meneliki & Yes & Yes \\
Civettictis civetta & No & Yes \\
Hystrix cristata & No & Yes \\
Orycteropus afer & No & Yes \\
Tragelaphus buxtoni & No & Yes
\end{tabular}

were observed during the wet season and $376 \pm 11(40.9 \%)$ during the dry season. The mean seasonal abundance of individuals was significant $\left(\chi^{2}=30.678, \mathrm{df}=1, p<0.05\right)$.

3.2. Relative Abundance. Colobus guereza was the most abundant $(38 \%, n=330 \pm 7)$ species, followed by olive baboon $(24 \%, n=224 \pm 5)$ and common warthog (12\%, $n=114 \pm 5$ ). Alternatively, serval cat, lion, and mountain nyala were the least abundant species $\left(0.1 \%, n_{1} \pm 0\right)$ (Table 3$)$. Seasonal variation was observed in species composition of large mammals among habitat types. The highest numbers of species $(n=16)$ were recorded in the intact MAF habitat during the wet season. The modified MAF habitat $(n=7)$ contained a considerably less number of species during both dry and wet seasons (Table 3 ). Seasonal variation in mean number of individuals was observed between the habitat types. The seasonal variation in mean number of individuals 

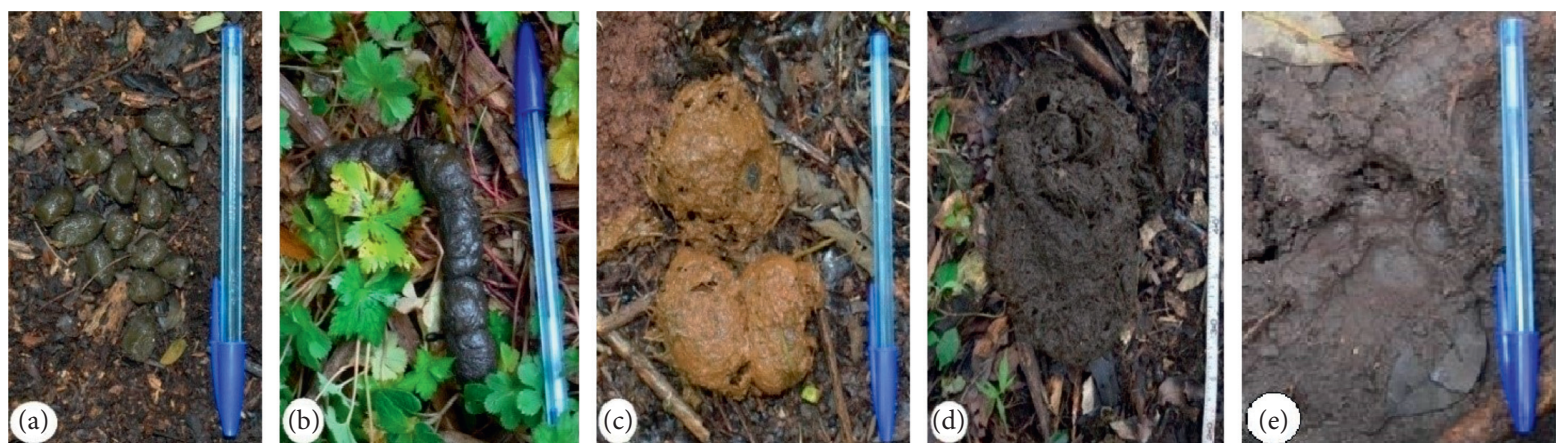

FIGURE 5: Scats and foot print of large mammals recorded at Nensebo forest, Southern Ethiopia. (a) Mountain nyala; (b) common jackal; (c) warthog; (d) giant forest hog; (e) leopard (photo: Zerubabel Worku, 2018).

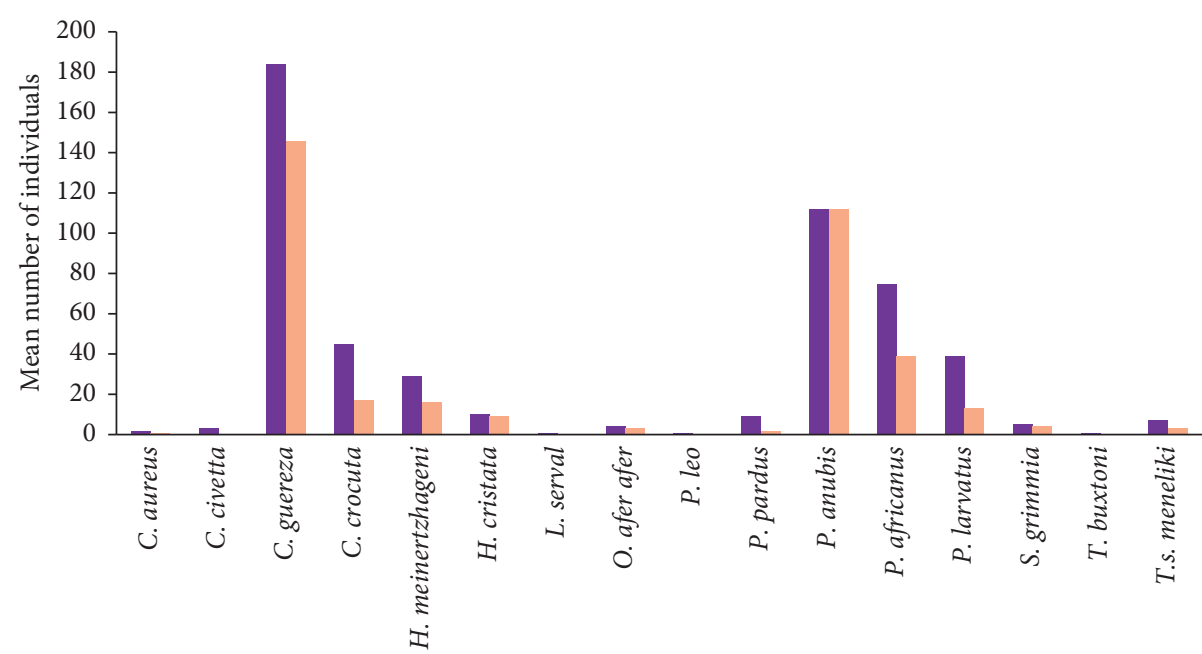

Species

- Wet season

Dry season

FIGURE 6: Seasonal variation in species composition and mean abundance of large wild mammals in Nensebo forest, Southern Ethiopia.

in intact $\operatorname{MAF}\left(\chi^{2}=45.134, \quad p<0.05 ; \quad\right.$ wet $=440 \pm 13$, dry $=262 \pm 9)$ was significant, and it was not significant in modified moist Afromontane forest habitat $\left(\chi^{2}=0.459\right.$, $p>0.05$; wet $=104 \pm 6$, dry $=114 \pm 4)($ Table 3$)$. The Sorensen species similarity index (CC) of large wild mammal species among the two habitat types was 0.64 .

3.3. Population Structure. The population structure of the most recorded species was characterized by more adult and few young individuals during both wet and dry seasons (Table 5). Alternatively, the number of adult females was relatively higher than adult males during both seasons. The pooled sex ratio of adult animals of all species was biased towards females, and the difference was significant, $t=138.471, \mathrm{df}=88, p<0.05$ and $t=44.675, \mathrm{df}=124, p<0.05$ during the wet and dry seasons, respectively.

\section{Discussion}

A total of 16 species of large mammals were identified during the study. This result can be compared with similar studies in different parts of Ethiopia that have similar ecology and have used similar techniques to census mammals. For example, previous research [41] identified 19 species of large wild mammals in and around Wondo Genet fragmented MAF. Reference [16] recorded 25 species of large- and mediumsized mammals in the Harenna MAF of Bale Mountains National Park (BMNP). The area is home to a diversity of wild mammals. Several other reports have also emphasized the importance of habitats outside of protected areas in supporting a diversity of wildlife species $[12,13]$. The existence of relatively higher numbers of endemic, rare, and endangered species in the area indicates that the landscape of the fragment forest that spans over altitudinal difference is 
TABLE 3: Relative abundance and mean abundance of large wild mammals among different habitat types of Nensebo forest, Southern Ethiopia.

\begin{tabular}{|c|c|c|c|c|c|c|}
\hline \multirow[t]{3}{*}{ NENSEBO } & \multicolumn{4}{|c|}{$\begin{array}{c}\text { Mean number of individuals observed in } \\
\text { different habitat types }\end{array}$} & \multirow{3}{*}{ Total animals observed } & \multirow{3}{*}{ Relative abundance (in \%) } \\
\hline & \multicolumn{2}{|c|}{$\begin{array}{l}\text { Moist Afromontane } \\
\text { forest }\end{array}$} & \multicolumn{2}{|c|}{$\begin{array}{l}\text { Modified moist } \\
\text { Afromontane forest }\end{array}$} & & \\
\hline & Wet & Dry & Wet & Dry & & \\
\hline C. guereza & 141 & 87 & 43 & 59 & $330 \pm 7$ & 38 \\
\hline P. anubis & 85 & 72 & 27 & 40 & $224 \pm 5$ & 24 \\
\hline P. africanus & 64 & 30 & 11 & 9 & $114 \pm 5$ & 12 \\
\hline C. crocuta & 40 & 16 & 5 & 1 & $62 \pm 3$ & 6.7 \\
\hline P. larvatus & 31 & 10 & 8 & 3 & $52 \pm 4$ & 5 \\
\hline H. meinertzhageni & 23 & 14 & 6 & 2 & $35 \pm 4$ & 3.8 \\
\hline H. cristata & 10 & 9 & 0 & 0 & $19 \pm 1$ & 2 \\
\hline T. s. meneliki & 6 & 3 & 1 & 0 & $10 \pm 0$ & 1 \\
\hline P. pardus & 9 & 2 & 0 & 0 & $11 \pm 1$ & 1.1 \\
\hline S. grimmia & 5 & 4 & 0 & 0 & $9 \pm 1$ & 0.9 \\
\hline O. afer & 4 & 3 & 0 & 0 & $7 \pm 0$ & 0.7 \\
\hline C. civetta & 3 & 0 & 0 & 0 & $3 \pm 0$ & 0.3 \\
\hline C. aureus & 2 & 1 & 0 & 0 & $3 \pm 1$ & 0.3 \\
\hline F. serval & 1 & 0 & 0 & 0 & $1 \pm 0$ & 0.1 \\
\hline P. leo & 1 & 0 & 0 & 0 & $1 \pm 0$ & 0.1 \\
\hline T. buxtoni & 1 & 0 & 0 & 0 & $1 \pm 0$ & 0.1 \\
\hline Total (16) & $440 \pm 13$ & $262 \pm 9$ & $104 \pm 6$ & $114 \pm 4$ & $920 \pm 21$ & $100 \%$ \\
\hline
\end{tabular}

Diversity indices: the highest large mammals Simpson's (1-D) and Shannon-Weaver index of diversity was obtained in the intact moist Afromontane forest habitat $\left(D=5.434, H^{\prime}=2.188\right)$, and the modified moist Afromontane forest habitat had the lowest diversity $\left(D=3.095, H^{\prime}=1.373\right)($ Table 4$)$.

TABLE 4: Diversity indices of large wild mammals indifferent habitat types of Nensebo forest, Southern Ethiopia.

\begin{tabular}{|c|c|c|c|c|c|c|}
\hline $\begin{array}{l}\text { Habitat types } \\
\text { effort }\end{array}$ & $\begin{array}{c}\text { Number } \\
\text { of } \\
\text { species }\end{array}$ & $\begin{array}{l}\text { Number of } \\
\text { individuals }\end{array}$ & $H^{\prime}$ & $D$ & $H_{\max }$ & $E$ \\
\hline $\begin{array}{l}\text { Area total } \\
(80 \mathrm{~km} \\
\text { walked }) \\
\end{array}$ & 16 & $920 \pm 21$ & & & & \\
\hline $\begin{array}{l}\text { Modified } \\
\text { moist } \\
\text { Afromontane } \\
\text { forest }(20 \mathrm{~km} \\
\text { walked) }\end{array}$ & 8 & $218 \pm 5$ & 1.373 & 3.095 & 2.079 & 0.660 \\
\hline $\begin{array}{l}\text { Moist } \\
\text { Afromontane } \\
\text { forest }(60 \mathrm{~km} \\
\text { walked) }\end{array}$ & 16 & $702 \pm 9$ & 2.188 & 5.434 & 2.833 & 0.772 \\
\hline
\end{tabular}

$E=$ Pielou evenness; $H^{\prime}=$ calculated Shannon-Weiner diversity; $H_{\max }=\ln (\mathrm{s})$ (species diversity under maximum equitability conditions); $D=$ Simpson's index.

an important area to maintain endemism and therefore should be given high conservation priority. Seasonal variations were observed in species composition of large wild mammals among different habitat types. The variation is credited to the seasonal variations in availability of water, food, and cover.

The distribution and habitat association of mammals are often correlated mainly with the availability of habitat components [42]. Seasonal variation in habitat quality (variation in food, cover, and water sources) may also contribute to the seasonal variation in species composition.
Additionally, the pattern of anthropogenic effects, such as livestock grazing and human settlements, may also influence such variation. For instance, seasonal difference in the level disturbance (deforestation and livestock grazing) was observed, which was inversely related with wild animal's abundance and distribution. During the field data collection, increased presence of livestock and human settlements was observed in the wet season that could initiate human-wildlife conflict. Various studies elsewhere have frequently reported that the level of disturbance in large mammals' habitat determines habitat use, and large mammals have been reported to avoid habitats with a high level of disturbance [7, 14-18, 42-47]. Similar results were reported in the Alatish National Park, Ethiopia [28, 43].

Primates are widely distributed in Africa over diverse habitat types [48]. Many primates, including olive baboon and Colobus guereza, are known to commonly inhabit the attitudinal range, from 1500 to $3700 \mathrm{~m}$ a.s.l (current altitudinal range) [41, 48]. However, the distribution and abundance of primates are also highly influenced by the abundance, availability, and distribution of resources like sleeping cliffs/trees, food, and water [41, 48, 49]. During this study, some nocturnal and cryptic species may have been under reported. This is due to the behavior of the animals, rareness of the species, and poor visibility due to darkness and thick vegetation that could contribute to poor visibility and fewer sightings.

The heterogeneous plant species assemblage in the intact moist MAF could have contributed to the recorded highest diversity of mammals in the study area. Such habitat provides more extensive browsing and grazing opportunities, and the greater diversity of vegetation in such areas is likely 
TABLe 5: Population structure of large wild mammals at Nensebo forest, Southern Ethiopia.

\begin{tabular}{|c|c|c|c|c|c|c|c|c|c|c|}
\hline \multirow[t]{2}{*}{ Species } & \multicolumn{2}{|c|}{ Total Ind. } & \multicolumn{2}{|c|}{$\begin{array}{l}\text { Classified Ind. } \\
(\%)\end{array}$} & \multicolumn{2}{|c|}{$\%$ young } & \multicolumn{4}{|c|}{ Ratio } \\
\hline & Wet & Dry & Wet & Dry & Wet & Dry & $\mathrm{M} / \mathrm{F}$ & $\mathrm{Y} / \mathrm{A}$ & $\mathrm{M} / \mathrm{F}$ & $\mathrm{Y} / \mathrm{A}$ \\
\hline C. aureus & 2 & 1 & 0 & 100 & - & - & - & - & - & - \\
\hline C. civetta & 3 & - & 0 & 0 & - & - & - & - & - & - \\
\hline C. guereza & 184 & 146 & 55 & 55 & 8.7 & 12 & $1: 1.4$ & $1: 0.04$ & $1: 1.6$ & $1: 0.08$ \\
\hline C. crocuta & 45 & 17 & 0 & 0 & - & - & - & - & - & - \\
\hline H. meinertzhageni & 29 & 16 & 0 & 0 & - & - & - & - & - & - \\
\hline H. cristata & 10 & 9 & 0 & 0 & - & - & - & - & - & - \\
\hline L. serval & 1 & 0 & 0 & 0 & - & - & - & - & - & - \\
\hline O. afer & 4 & 3 & 0 & 0 & - & - & - & - & - & - \\
\hline P. leo & 1 & 0 & 0 & 0 & - & - & - & - & - & - \\
\hline P. pardus & 9 & 2 & 0 & 0 & - & - & - & - & - & - \\
\hline P. anubis & 112 & 112 & 94 & 67 & 25 & 20.5 & $1: 1.4$ & $1: 0.2$ & $1: 2$ & $1: 0.2$ \\
\hline P. africanus & 75 & 39 & 12 & 7.7 & - & - & $1: 2$ & - & $1: 2$ & - \\
\hline P. larvatus & 39 & 13 & 7.7 & 0 & - & - & $1: 2$ & - & - & - \\
\hline S. grimmia & 5 & 4 & 60 & 50 & - & - & $1: 2$ & - & $1: 1$ & - \\
\hline T. buxtoni & 1 & 0 & 0 & 0 & - & - & - & - & - & - \\
\hline T. s. meneliki & 7 & 3 & 14 & 33 & - & - & - & - & - & - \\
\hline
\end{tabular}

$\mathrm{F}=$ female; $\mathrm{M}=$ male; Ind = individuals; $\mathrm{Y}=$ young.

to support larger numbers of prey species. Several scholars $[43,47,50]$ have also previously reported a positive correlation between habitat heterogeneity and animal species diversity. As a result, large-sized mammal distribution and diversity in the present study areas were highly associated with habitat characteristics.

A previous report [17] reported a high diversity and evenness of medium- and large-sized mammals in BorenaSayint National Park, South Wolo, Ethiopia, which has diversified habitat types. On the contrary, habitat homogeneity was reported to have lower diversity $[43,51,52]$. The knowledge of sex ratio and age distribution of individual mammals is vital for evaluating the viability of a species because these variables reflect the structure and the dynamics of populations. As a result, the higher proportion of females and young indicate a healthy, increasing population. Even though the total proportion of adults (male and female) was higher, the number of adult males was low. The cause for the low proportion of adult males in most of the species could be a natural distribution of sex ratios; in naturally growing population adult males proportion is lower than adult females, due to the fact that a single male and copulate with more than female, since most mammals are polygamous. It might be also related to poaching pressure, in which the adult males are mostly selected by poachers [53]. Culturally, the indigenous community prefers to hunt adult males for food, medicine, and cultural rituals over females and other age groups. Due to poor habitat, quality competition of males to mate and resources could also force the bachelor males to migrate to less suitable habitats that are poor in food quality and exposing them to predators and poachers [54], which could also be another reason for the lower record of adult males [54].

The results of the study on species diversity has revealed high species diversity and endemism over relatively small fragmented forest, and this is an important input to underpin sound wildlife conservation management options in the area. The results of the study also indicated high abundance of primates, which is important information for proposing primates management options in the area. The population structure study is also an important source of information for population management of the large mammals recorded in the forest fragment.

\section{Conclusion}

The results of the study indicated relatively high large mammals diversity in fragmented remote forest and calls for conservation attention. It can also be concluded that forest degradation (modified forest) leads to decline in large mammals abundance. Relatively primates are the most abundant in the fragment forest. The results of the study also indicated an increasing primates population in the future due to relatively higher young individuals, whereas the absence of young individuals in large carnivores and large herbivores could indicate population decline.

\section{Data Availability}

The data used to support the findings of this study are available from the corresponding author upon request.

\section{Conflicts of Interest}

The authors declare that they have no conflicts of interest.

\section{Acknowledgments}

The authors would like to thank Hawassa University, for financial support, and Wondo Genet College of Forestry and Natural Resources for all the logistics. The authors are also very thankful to the staff of Nensebo Woreda Administration Office, Rural Land Administration Office, and Tourism and Communication Office for the welcoming and cooperative environment. A special word of thanks goes to our 
field assistants. This study was funded by Hawassa University First Round Thematic Research Grant Year 2016-17.

\section{References}

[1] D. E. Wilson and D. M. Reeder, Mammal Species of the Worldp. 2142, 3rd edition, Johns Hopkins University Press, Baltimore, MD, USA, 2005.

[2] J. Novotny and M. Pankova, The Orbis Pocket, Encyclopedia of the World, Orbis, London, UK, 1981.

[3] R. L. Jefferies, D. R. Klein, and G. R. Shaver, "Vertebrate herbivores and northern plant communities: reciprocal influences and responses," Oikos, vol. 71, no. 2, pp. 193-206, 1994.

[4] R. Lapeyre, Y. Laurans, and Y. Laurans, "Contractual arrangements for financing and managing African protected areas: insights from three case studies," Parks, vol. 23, no. 1, pp. 75-88, 2017.

[5] World Travel and Tourism, The Economic Impact of Global Wildife Tourism: Travel \& Tourism as an Economic Tool for the Protection of Wildlife, 2019, https://travesiasdigital.com/wpcontent/uploads/2019/08/The-Economic-Impact-of-GlobalWildlife-Tourism-Final-19.pdf.

[6] D. A. Duffus and P. Dearden, "Non-consumptive wildlifeoriented recreation: a conceptual framework," Biological Conservation, vol. 53, pp. 13-231, 1990.

[7] C. N. Jenkinsa, S. L. Pimmb, and L. N. Joppac, "Global patterns of terrestrial vertebrate diversity and conservation," Proceedings of the National Academy of Sciences of the United States of America, vol. 110, no. 28, pp. E2602-E2610, 2013.

[8] J. W. Sutherland, Ecological Census Techniques, University of East Anglia, Norwich, UK, 2nd edition, 2006.

[9] M. Wolde-Mariam, An Atlas of Ethiopia, Haile Selassie University Press, Addis Ababa, Ethiopia, 1969.

[10] "Ethiopian protected areas: a snapshot," 2019, https:// phe389ethiopia.org/admin/uploads/attachment-1167Eth\% 20Protected\%20Areas\%20Snapshot\%201_4_2012.pdf.

[11] A. Bekele and D. W. Yalden, The Mammals of Ethiopia and Eritrea, Addis Ababa University Press, Addis Ababa, Ethiopia, 2013.

[12] World Conservation Monitoring Centre (WCMC), Biodiversity Data Sourcebook, p. 168, WCMC, Cambridge, UK, 1994.

[13] Ethiopian Biodiversity Institute (EBI), Ethiopia's Fifth $\mathrm{Na}$ tional Report to the Convention on Biological Diversity, EBI, Addis Ababa, Ethiopia, 2014.

[14] T. Melaku, "Wildlife in Ethiopia: large endemic mammals," Current Zoology, vol. 6, pp. 108-116, 2011.

[15] G. Mengesha and A. Bekele, "Diversity, distribution and habitat association of large mammals of Alatish, North Gonder Ethiopia," Current Zoology, vol. 54, pp. 20-29, 2008.

[16] A. Bekele, "A census of large wild mammals in the Harenna forest Ethiopia," SINET: Ethiopian Journal of Science, vol. 11, pp. 27-39, 1988.

[17] M. Chane and S. Yirga, "Diversity of medium and large-sized mammals in borena-sayint national park, South Wollo, Ethiopia," International Journal of Science, vol. 15, pp. 95-106, 2009.

[18] A. Fetene, G. Mengesha, and T. Bekele, "Spatial distribution and habitat preferences of selected large mammalian species in the NechSar National Park (NSNP), Ethiopia," Natural Sciences, vol. 9, no. 3, pp. 80-90, 2011.
[19] NenseboWoreda Tourism and Communication Office (NWTCO), A Magazine; General Information about Nensebo Woreda, NWTCO Publications, Woreka, Ethiopia, 2003.

[20] E. Getachew, "Floristic diversity and disturbances in Nensebo and Geremba remnant forests, South Eastern Ethiopia," M.Sc. thesis, Hawassa University, Hawassa, Ethiopia, 2019.

[21] Z. Work and Z. Girma, "Large Mammal diversity and endemism at Geremba Mountain fragment, southern Ethiopia," International Journal of Ecology, p. 11, Article ID 3840594, 2020.

[22] A. Zewdu, "Knowledge and attitude of local community towards wildlife conservation in Arbegona and NenseboWoredas, Ethiopia," M.Sc. Thesis, Hawassa University, Hawassa, Ethiopia, 2018.

[23] Environmental Systems Research Institute (ESRI), Arc GIS Software 10.1, Environmental Systems Research Institute, Redlands, CA, USA, 2012.

[24] C. Peres, "General guidelines for standardizing line-transect surveys of tropical forest primates," Neotropical Primates, vol. 7, pp. 11-16, 1999.

[25] C. A. Peres and A. Cunha, "Line-transect censuses of largebodied tropical forest vertebrates: a handbook," Wildlife Conservation Society, Brazilia, Brazil, 2011.

[26] A. Singh, A. Mukherjee, S. Dookia, and H. N. Kumara, "An updated Account of mammal species and population status of ungulates in Keoladeo national park, bharatpur, Rajasthan," Current Science, vol. 113, no. 1, p. 103, 2017.

[27] L. H. Emmons and F. Feer, Neo-tropical Rainforest Mammals Field Guide, The University of Chicago Press, Chicago, IL, USA, 1997.

[28] B. Shrestha and K. Basnet, "Indirect methods of identifying mammals: a case study from Shivapuri National Park, Nepal," International Journal of Ecology, vol. 12, pp. 43-57, 2005.

[29] J. Kingdon, The Kingdon Field Guide to African Mammals, Academic Press, London, UK, 1997.

[30] S. Yirga, Atibiwoch, Ethiopian Wildlife and Natural History Society, Addis Ababa, Ethiopia, 2008.

[31] G. Ohnesorge and B. Scheiba, Tierspuren and Fährten in Feld und Wald, Bassermann Verlag, München, German, 2007.

[32] D. MacDonald and P. Barrett, Mammals of Europe, Princeton University Press, Princeton, NJ, USA, 2002.

[33] P. Bang and P. Dahlstrom, Animal Tracks and Signs, Oxford University Press, Oxford, UK, 2001.

[34] The IUCN Red List of species Version 2016, 2019, http://www. iucnredlist.org/details/on-2017-1-292016.

[35] J. Hillman, Ethiopia: Compendium of Wildlife Conservation Information, Ethiopian Wildlife Conservation Organization, Addis Ababa, Ethiopia, 1993.

[36] C. E. Shannon and W. Weaver, The Mathematical Theory of Communication, University of Illinois Press, Urbana, IL, USA, 1949.

[37] E. H. Simpson, "Measurement of diversity," Nature, vol. 163, no. 4148, p. 688, 1949.

[38] T. Sørensen, "A method of establishing groups of equal amplitude in plant sociology based on similarityof species and its application to analyses of the vegetation on Danish commons," BiologiskeSkrifter/KongeligeDanskeVidenskabernesSelskab, vol. 5, pp. 1-34, 1957.

[39] E. C. Pielou, "The measurement of diversity in different types of biological collections," Journal of Theoretical Biology, vol. 13, pp. 131-144, 1966.

[40] R. H. Whittaker, "Evolution and measurement of species diversity," Taxon, vol. 21, no. 2-3, pp. 213-251, 1972. 
[41] Z. Girma, Y. Mamo, and M. Ersado, "Species composition, distribution and relative abundance of large mammals in and around Wondo Genet forest patch, Southern Ethiopia," Asian Journal of Applied Sciences, vol. 5, no. 8, pp. 538-551, 2012.

[42] T. Mekonnin, M. Yaba, A. Bekele, and J. Malcolm, "Food selection and habitat association of starck's hare (Lepus starcki Petter, 1963) in bale mountains national park Ethiopia," Asian Journal of Applied Sciences, vol. 4, pp. 728-734, 2011.

[43] J. Tews, U. Brose, V. Grimm et al., "Animal species diversity driven by habitat heterogeneity/diversity: the importance of keystone structures," Journal of Biogeography, vol. 31, no. 1, pp. 79-92, 2004.

[44] P. H. Evangelista, J. Norman, L. Berhanu, S. Kumar, and N. Alley, "Predicting habitat suitability for the endemic mountain nyala (Tragelaphus buxtoni) in Ethiopia," Wildlife Research, vol. 35, no. 5, pp. 409-416, 2008.

[45] Y. Mamo and A. Bekele, "Human and livestock encroachments into the habitat of mountain nyala (Tragelaphusbuxtoni) in the bale mountains national park, Ethiopia," Tropical Ecology, vol. 52, pp. 265-273, 2011.

[46] Z. Girma, A. Bekele, and H. Graham, "Large mammals and mountain encroachments on mount Kaka and hunkolo fragments, southeast Ethiopia," Asian Journal of Applied Sciences, vol. 5, no. 5, pp. 279-289, 2012.

[47] Z. Girma, G. Chuyong, P. Evanagelsita, and Y. Mamo, "Habitat characterization and preferences of the mountain nyala (Tragelaphusbuxtoni, Lydekker 1910) and Menelik's bushbuck (Tragelaphusscriptusmeneliki, Neumann 1902) in Arsi mountains national park, south-eastern Ethiopia," International Journal of Current Research, vol. 7, pp. 2307423082, 2015.

[48] United Nations Economic, Social and Cultural Organization (UNESCO), Faunal Survey-Final Report on Status and Distribution of Faunal Diversity in Kaffa Afro-Montane Forest, UNESCO, Addis Ababa, Ethiopia, 2008.

[49] A. L. Schreier and M. Grove, "Ranging patterns of hamadryas baboons: random walk analyses," Animal Behaviour, vol. 80, no. 1, pp. 75-87, 2010.

[50] R. T. Paine, "Phycology for the Mammalogist: Marine Rocky shores and mammal-dominated communities-how different are the structuring Processes?" Journal of Mammalogy, vol. 81, no. 3, pp. 637-648, 2000.

[51] C. Bonnington, D. Weaver, and E. Fanning, "Livestock and large wild mammals in the Kilombero valley, in Southern Tanzania," African Journal of Ecology, vol. 45, no. 4, pp. 658-663, 2007.

[52] D. W. Yalden and M. J. Largen, "The endemic mammals of Ethiopia," Mammal Review, vol. 22, no. 3-4, pp. 115-150, 1992.

[53] E. Gundogdu, "Population size, structure and behaviors of wild goat in Cehennemdere wild life improvement area," Asian Journal of Animal and Veterinary Advances, vol. 6, pp. 55-563, 2011.

[54] Y. Mamo, A. Bekele, and G. Mengesha, "Habitat use of mountain nyala (Tragelaphusbuxtoni, Lyddeker, 1911) in the bale mountains national park, Ethiopia," International Journal of Biodiversity and Conservation, vol. 4, pp. 642-651, 2012. 